\title{
Fixation and defixation of ammonium in soils: a review
}

\author{
Rolf Nieder • Dinesh K. Benbi • Heinrich W. Scherer
}

Received: 11 December 2009/Revised: 22 September 2010/Accepted: 24 September 2010 / Published online: 12 October 2010

(C) The Author(s) 2010. This article is published with open access at Springerlink.com

\begin{abstract}
Fixed $\mathrm{NH}_{4}^{+}\left(\mathrm{NH}_{4}^{+}\right.$f) and fixation and defixation of $\mathrm{NH}_{4}^{+}$in soils have been the subject of a number of investigations with conflicting results. The results vary because of differences in methodology, soil type, mineralogical composition, and agro-climatic conditions. Most investigators have determined $\mathrm{NH}_{4}{ }_{\mathrm{f}}^{+}$using strong oxidizing agents $(\mathrm{KOBr}$ or $\mathrm{KOH})$ to remove organic $\mathrm{N}$ and the remaining $\mathrm{NH}_{4}{ }_{\mathrm{f}}^{+}$does not necessarily reflect the fraction that is truly available to plants. The content of native $\mathrm{NH}_{4}{ }_{\mathrm{f}} \mathrm{f}$ in different soils is related to parent material, texture, clay content, clay mineral composition, potassium status of the soil and $\mathrm{K}$ saturation of the interlayers of 2:1 clay minerals, and moisture conditions. Evaluation of the literature shows that the $\mathrm{NH}_{4}{ }_{\mathrm{f}}^{+} \mathrm{N}$ content amounts to $10-90 \mathrm{mg} \mathrm{kg}^{-1}$ in coarse-textured soils (e.g., diluvial sand, red sandstone, granite), $60-270 \mathrm{mg} \mathrm{kg}^{-1}$ in medium-textured soils (loess, marsh, alluvial sediment, basalt) and $90-460 \mathrm{mg} \mathrm{kg}^{-1}$ in fine-textured soils (limestone, clay stone). Variable results on plant availability of $\mathrm{NH}_{4}{ }_{\mathrm{f}}^{+}$are mainly due to the fact that some investigators distinguished between native and recently fixed $\mathrm{NH}_{4}{ }^{+}$while others did not. Recently fixed $\mathrm{NH}_{4}{ }^{+}$is available to plants to a greater degree than the
\end{abstract}

\footnotetext{
R. Nieder $(\bowtie)$

Institute of Geoecology, Technische Universität Braunschweig, Langer Kamp 19c,

38106 Braunschweig, Germany

e-mail: r.nieder@tu-bs.de

D. K. Benbi

Department of Soils, Punjab Agricultural University,

Ludhiana 141004, India

H. W. Scherer

INRES - Plant Nutrition, University of Bonn,

Karlrobert-Kreiten-Straße 13,

53115 Bonn, Germany
}

native $\mathrm{NH}_{4}{ }_{\mathrm{f}}$, and soil microflora play an important role in the defixation process. The temporal changes in the content of recently fixed $\mathrm{NH}_{4}^{+}$suggest that it is actively involved in $\mathrm{N}$ dynamics during a crop growth season. The amounts of $\mathrm{NH}_{4}{ }^{+}$defixed during a growing season varied greatly within the groups of silty $\left(20-200 \mathrm{~kg} \mathrm{NH}_{4}^{+}-\mathrm{N} \mathrm{ha}^{-1} 30 \mathrm{~cm}^{-1}\right)$ as well as clayey (40-188 $\mathrm{kg} \mathrm{NH}_{4}{ }^{+}-\mathrm{N} \mathrm{ha}^{-1} 30 \mathrm{~cm}^{-1}$ ) soils. The pool of recently fixed $\mathrm{NH}_{4}{ }^{+}$may therefore be considered in fertilizer management programs for increasing $\mathrm{N}$ use efficiency and reducing $\mathrm{N}$ losses from soils.

Keywords Fixed $\mathrm{NH}_{4}{ }^{+}\left(\mathrm{NH}_{4}{ }_{\mathrm{f}}^{+}\right) \cdot$ Native $\mathrm{NH}_{4}{ }_{\mathrm{f}}$. Recently fixed $\mathrm{NH}_{4}{ }^{+} \cdot \mathrm{N}$ dynamics $\cdot \mathrm{NH}_{4}{ }_{\mathrm{f}}^{+}$availability to plants and microflora

\section{Introduction}

Some soils are able to bind ammonium $\left(\mathrm{NH}_{4}{ }^{+}\right)$and potassium $\left(\mathrm{K}^{+}\right)$in such a manner that these cannot be easily replaced by other cations. McBeth (1917) was the first who observed that $\mathrm{NH}_{4}{ }^{+}$added to soils could not be completely recovered by alkaline distillation or by extraction with 10\% hydrochloric acid. McBeth (1917) defined the unrecovered portion of the added $\mathrm{NH}_{4}{ }^{+}$as "fixed $\mathrm{NH}_{4}{ }^{+}$", (henceafter refered as $\mathrm{NH}_{4}{ }^{+}$f). The fixation of $\mathrm{NH}_{4}{ }^{+}$is defined as "the adsorption or absorption of ammonium ions by the mineral or organic fraction of the soil in a manner that they are relatively unexchangeable by the usual methods of cation exchange" (Osborne 1976a; SSSA 1984). Osborne (1976a) suggested "intercalary $\mathrm{NH}_{4}^{+}$" and Mengel and Scherer (1981) "non-exchangeable $\mathrm{NH}_{4}{ }^{+}$" to distinguish between the $\mathrm{NH}_{4}{ }^{+}$recovered from clay minerals by digestion of the soil with $5 \mathrm{~N} \mathrm{HF}: 1 \mathrm{~N} \mathrm{HCl}$ and $\mathrm{NH}_{4}{ }^{+}$ which is bound organically or as $\mathrm{NH}_{4}$-phosphate (Frye and 
Hutcheson 1981). While earlier investigations concluded that only a very small amount of $\mathrm{NH}_{4}{ }_{\mathrm{f}}$ is available to microorganisms and plants (Allison et al. 1951, 1953b; Axley and Legg 1960; Lutz 1966), studies in the last three decades suggest that $\mathrm{NH}_{4}{ }_{\mathrm{f}}^{+}$may be released and used by crops (Kudeyarov 1981; Nommik 1981; Mengel and Scherer 1981; 1986; Nommik and Vahtras 1982; Preston 1982; Scherer 1984, 1987, 1993; Lu et al. 2010).

Ammonium fixation and release can play a crucial role for the efficiency of fertilizer N (Scherer and Mengel 1986; Dou and Steffens 1995; Steffens and Sparks 1999; Juang et al. 2001) as it impacts the indigenous soil $\mathrm{N}$ supply towards crop $\mathrm{N}$ uptake. Nitrogen contributions from soil including defixation of $\mathrm{NH}_{4}{ }_{\mathrm{f}}^{+}$in a given year/season can greatly alter recovery efficiency of applied $\mathrm{N}$ because there occurs a large fertilizer $\mathrm{N}$ substitution of soil $\mathrm{N}$. With current concerns about the environment and the need to produce more food with less fertilizer $\mathrm{N}$ input there is an increased focus for quantifying soil borne $\mathrm{N}$ supply. The need to boost agricultural production worldwide is stimulating $\mathrm{N}$ fertilizer consumption. In Asia and the Americas, ammonium-based N fertilizers are increasingly used (Prud'homme 2005) and their recovery efficiency by the plants, inter alia, could be influenced by fixation and release of $\mathrm{NH}_{4}{ }^{+}$. In soils with high $\mathrm{NH}_{4}^{+}$fixation capacity a part of the $\mathrm{NH}_{4}^{+}$supplied through $\mathrm{NH}_{4}{ }^{+}$-forming or $\mathrm{NH}_{4}{ }^{+}$-containing fertilizers may be bound in clay mineral interlayers. Increasing $\mathrm{NH}_{4}^{+}$ fixation can be a way in building up an available $\mathrm{N}$ pool in soils to optimize crop recovery and minimize $\mathrm{N}$ losses into the environment (Liu et al. 2008) as the $\mathrm{NH}_{4}{ }^{+}$ions after penetration into the clay mineral interlayers are excluded from nitrification (Guo et al. 1983) and are thus protected against leaching. The $\mathrm{NH}_{4}{ }^{+} \mathrm{f}$ pool can thus function as a kind of buffer that could influence $\mathrm{N}$ losses from soils and mineral $\mathrm{N}$ availability to crops.

Some reviews on the fixation and availability of fixed $\mathrm{NH}_{4}{ }^{+}$have been published in the past (Rodrigues 1954; Nommik 1957; Bremner 1959; Nommik and Vahtras 1982; Scherer 1993). These reviews mainly focused on the chemistry and factors influencing $\mathrm{NH}_{4}{ }^{+}$fixation in soils and gave relatively less attention to the seasonal dynamics and plant availability of $\mathrm{NH}_{4}{ }^{+} \mathrm{f}$. While the chemistry of $\mathrm{NH}_{4}{ }^{+}$fixation is fairly well understood (Baethgen and Alley 1987; Nommik and Vahtras 1982), there are conflicting reports on the availability of $\mathrm{NH}_{4}{ }^{+} \mathrm{f}$. This is assumed to be due to differences in methodology, soil type, mineralogical composition, and agro-climatic conditions. It is, therefore, important that the existing information may be integrated with underlying variants for better understanding the role of $\mathrm{NH}_{4}{ }^{+}$fixation and release on $\mathrm{N}$ dynamics in the soil-plant system.

The present paper gives an overview of the current knowledge on $\mathrm{NH}_{4}{ }_{\mathrm{f}}$ and ammonium fixation and defix- ation, particularly on pool sizes in different soils with particular emphasis on new aspects on availability of recently fixed $\mathrm{NH}_{4}^{+}$to crops and microflora and seasonal changes of $\mathrm{NH}_{4}^{+}$f pools under plant cover. The information is important not only for fertilizer management but also on the background of increasing importance of $\mathrm{NH}_{4}{ }^{+}$-based fertilization, namely urea, and an intensive debate on $\mathrm{NH}_{4}{ }^{+}$based fertilization (cultan fertilization) in plant nutrition (Sommer and Scherer 2009). The paper includes literature of the last few decades, and the soils were grouped according to parent material and texture.

\section{Methods for the determination of $\mathrm{NH}_{4}{ }_{\mathrm{f}}$}

Several methods have been proposed for determining $\mathrm{NH}_{4}{ }_{\mathrm{f}}$ in soil. Most of the methods involve pretreatment of the samples to remove organic matter and exchangeable $\mathrm{NH}_{4}{ }^{+}$and dissolution/extraction of the residual sample for release of $\mathrm{NH}_{4}^{+} \mathrm{f}$. Barshad (1951) suggested distilling $\mathrm{NH}_{4}{ }^{+}$-treated soil with $\mathrm{NaOH}$ and $\mathrm{KOH}$ to remove exchangeable $\mathrm{NH}_{4}{ }^{+}$. This method resulted in an incomplete recovery in some cases probably because of blocking effect of $\mathrm{K}^{+}$or interference by soil organic matter. In the method by Mogilevkina (1964), soil organic matter is removed by dry combustion at $400^{\circ} \mathrm{C}$ during time periods between 24 and $72 \mathrm{~h}$, depending on the organic matter content, prior removal of the fixed $\mathrm{NH}_{4}{ }^{+}$using sulfuric acid (Kjeldahl procedure). Most of the other methods use HF for the extraction of $\mathrm{NH}_{4}{ }_{\mathrm{f}}$ (Rodrigues 1954; Dhariwal and Stevenson 1958; Bremner 1959). The method proposed by Silva and Bremner (1966) is the most commonly used and involves treating the soil with alkaline $\mathrm{KOBr}$ solution (to remove organic compounds), washing the residue with $0.5 \mathrm{M} \mathrm{KCl}$ and shaking with $5 \mathrm{~N} \mathrm{HF}: 1 \mathrm{~N} \mathrm{HCl}$ for $24 \mathrm{~h}$. The $24 \mathrm{~h}$ time for $\mathrm{HF}-\mathrm{HCl}$ treatment could be reduced to 30 min by performing the treatment at $100^{\circ} \mathrm{C}$. $\mathrm{The}^{\mathrm{NH}_{4}}{ }^{+}$ released is determined by steam distillation of the soil-acid mixture after adding $\mathrm{KOH}$. The pretreatment used in this method to remove organic compounds is considered superior to those used in previous methods for estimating fixed ammonium because it effects an almost entire removal of organic soil $\mathrm{N}$ without the risk of fixation of $\mathrm{NH}_{4}{ }^{+}$by soil minerals. Zhang and Scherer (1998) suggested replacing the boiling of the mixture of soil and $\mathrm{KOBr}$ on a hot plate with keeping the soil- $\mathrm{KOBr}$ mixture for 10 min either in a water bath at $95^{\circ} \mathrm{C}$ or heating in a microwave oven $(1,150 \mathrm{~W})$ at $50 \%$ of full power for 10 min. Marzadori et al. (1994) boiled the soil- $\mathrm{KOBr}$ mixture in a microwave digestion system for $5 \mathrm{~min}$ at $90 \%$ and $2 \mathrm{~min}$ at $80 \%$ of the maximum oven energy $(600 \mathrm{~W})$. Antisari et al. (1987) used $\mathrm{H}_{2} \mathrm{O}_{2}$ along with pyrophosphate and $\mathrm{NaCl}\left(\mathrm{H}_{2} \mathrm{O}_{2}-\mathrm{NaCl}\right)$ for the destruction of organic matter 
and the reproducibility of their method was better than that of the Silva and Bremner (1966) method. The method of Paramasivam and Breitenbeck (2000) excludes the alkaline pretreatment that removes labile organic compounds. Cox et al. (1996) suggested the use of sodium tetraphenylboron $\left(\mathrm{NaBPh}_{4}\right)$ that facilitates the release of $\mathrm{NH}_{4}{ }_{\mathrm{f}}^{+}$as $\mathrm{NH}_{4} \mathrm{BPh}_{4}$. However, compared with the method of Silva and Bremner (1966), only $71 \%$ of $\mathrm{NH}_{4}^{+} \mathrm{f}$ were extracted. Although the method may extract only a part of the $\mathrm{NH}_{4}{ }^{+}$, it may be a better estimate of potentially plant-available $\mathrm{NH}_{4}{ }^{+}$(Cox et al. 1996).

Comparison of some of the methods showed that these give widely different values for a given amount of $\mathrm{NH}_{4}{ }^{+}$f. For example, the method of Mogilevkina (1964) could recover only a quarter while the rest was lost during ignition of the soil sample to remove organic matter (Bremner et al. 1967). Similarly, Moyano and Gallardo (1988) also obtained significantly lower values with the method of Mogilevkina (1964) as compared to that of Silva and Bremner (1966). The method of Silva and Bremner (1966) gave higher values than the Dhariwal and Stevenson (1958), Bremner (1959), and Mogilevkina (1964) methods and lower values than the Rodrigues (1954) and Schachtschabel (1960) methods (Silva and Bremner 1966; Osborne 1976a).

Dixit and Mir (1987) compared the methods proposed by Rodrigues (1954), the modified Rodrigues method (Bremner et al. 1967) and those by Dhariwal and Stevenson (1958), Bremner (1959), and Silva and Bremner (1966) on ten soils varying in clay content from $12 \%$ to $31 \%$. The highest values were obtained in the method of Rodrigues and the lowest by the method of Bremner. Similar results were reported by Opuwaribo and Odu (1974). Antisari and Sequi (1988) compared results after the application of three methods (Silva and Bremner's method, $\mathrm{HF}-\mathrm{HCl}$ treatment in a microwave system, and $\mathrm{CHN}$ analyzer). The microwave system and CHN analyzer produced similar results and the values were generally 1.5 to 2.7 times higher than those obtained with Silva and Bremner's treatment indicating incomplete recovery by the latter method.

\section{Mechanism of $\mathrm{NH}_{4}{ }^{+}$fixation}

Ammonium fixation is greatest in 2:1 type clay minerals such as illite, vermiculite, and montmorillonite. Clay minerals possess negative charges balanced by cations, for example, $\mathrm{NH}_{4}^{+}$or $\mathrm{K}^{+}$. The physics of $\mathrm{NH}_{4}^{+}$is closely related to that of $\mathrm{K}^{+}$because both ions have similar ionic radii and low hydration energy. The complete concept with all its further aspects has been nicely put down in detail by Nommik (1965). For both $\mathrm{NH}_{4}^{+}$and $\mathrm{K}^{+}$, the same mechanism is responsible for fixation and both fit exactly into the ditrigonal holes in the basal oxygen plane of 2:1 clay minerals. The penetration of both cations into the clay mineral interlayers causes the clay layers to collapse to $1 \mathrm{~nm}$, and $\mathrm{NH}_{4}^{+}$and $\mathrm{K}^{+}$ions are trapped between silicate sheets and largely withdrawn from exchange reactions (Nommik 1965). Therefore, both cations held in the interlayers of collapsed 2:1 clay minerals are said to be "fixed" and the term "fixed $\mathrm{NH}_{4}^{+}$" was formerly used. The electrostatic energy between $\mathrm{NH}_{4}^{+}$(or $\mathrm{K}^{+}$) and the negative charges in the crystal sheets is greater than the hydration energy of ammonium. The $\mathrm{NH}_{4}^{+}$ion readily sheds its hydration water shell and enters the lattice void, where fixation occurs (Kittrick 1966).

\section{Contents of $\mathrm{NH}_{4}{ }_{\mathrm{f}}$ in soils and influencing factors}

Contents of $\mathrm{NH}_{4}^{+} \mathrm{f}$

Contents of $\mathrm{NH}_{4}^{+} \mathrm{f}^{-} \mathrm{N}$ in the plough layer of arable soils cover a wide range (Table 1). Parent material has a major influence on the $\mathrm{NH}_{4}{ }^{+} \mathrm{f}-\mathrm{N}$ pool in soils developed from different parent materials, which increases in the order sand (diluvial sand and red sandstone) $<$ basalt $\approx$ granite $<$ loess $\approx$ ground moraine $<$ alluvial sediment $<$ limestone $<$ marsh sediment. The high discrepancy in the $\mathrm{NH}_{4}{ }^{+} \mathrm{f}-\mathrm{N}$ content of soils that developed from clay stone (Mohammed 1979 vs. Zhang et al. 2007) may be mainly due to different clay mineralogy (note that the clay contents given by Zhang et al. (2007) only represent the fraction $<1 \mu \mathrm{m}$ ). In summary, the $\mathrm{NH}_{4}{ }^{+} \mathrm{f}-\mathrm{N}$ content amounts to $10-90 \mathrm{mg} \mathrm{kg}^{-1}$ in coarsetextured soils (e.g. diluvial sand, red sandstone, granite), 60-270 mg kg${ }^{-1}$ in medium-textured soils (loess, marsh, alluvial sediment, basalt), and $90-460 \mathrm{mg} \mathrm{kg}^{-1}$ in finetextured soils (limestone, clay stone).

At the regional scale, the contents of $\mathrm{NH}_{4}{ }^{+} \mathrm{f}-\mathrm{N}$ also vary considerably. For example, the content of $\mathrm{NH}_{4}^{+} \mathrm{f}_{\mathrm{f}} \mathrm{N}$ of different soils in Austria ranged between 45 and $190 \mathrm{mg} \mathrm{kg}^{-1}$ (Schiller and Wallicord 1964), of Spanish soils between 180 and $490 \mathrm{mg} \mathrm{kg}^{-1}$ (Moyano and Gallardo 1988), of soils in Turkey between 60 and $230 \mathrm{mg} \mathrm{kg}^{-1}$ (Elmaci et al. 2002), of soils in Queensland (Australia) between 6 and $107 \mathrm{mg} \mathrm{kg}^{-1}$ (Osborne 1976b), of soils of the former USSR between 40 and $490 \mathrm{mg} \mathrm{kg}^{-1}$ (Skonde et al. 1974), of soils in China between 35 and $573 \mathrm{mg} \mathrm{kg}^{-1}$ (Qi-Xiao et al. 1995), of soils in Nigeria between 8 and $98 \mathrm{mg} \mathrm{kg}^{-1}$ (Opuwaribo and Odu 1974), and of soils in southern Ontario (Canada) between 57 and $367 \mathrm{mg} \mathrm{kg}^{-1}$ non-exchangeable $\mathrm{NH}_{4}-\mathrm{N}$ (Doram and Evans 1983). The content in soils in Kentucky (USA) was as high as $365 \mathrm{mg} \mathrm{kg}^{-1}$ (Sparks et al. 1979). Investigations on top soils from Antarctic also showed that $\mathrm{NH}_{4}^{+} \mathrm{f}-\mathrm{N}$ occurs in amounts $\left(0\right.$ to $\left.322 \mathrm{mg} \mathrm{kg}^{-1}\right)$ similar to elsewhere in the world (Greenfield 1991). 


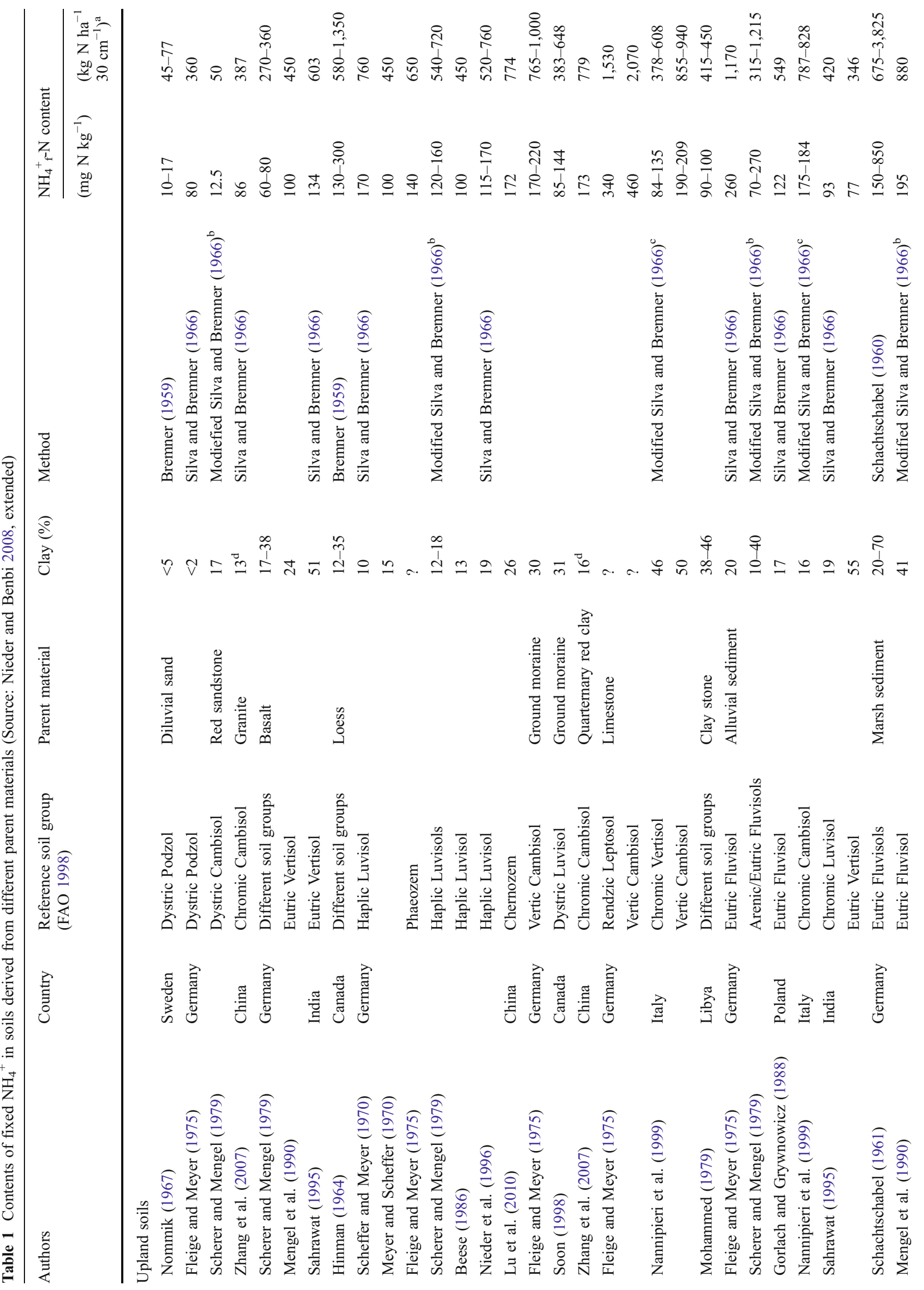


The percentage of total $\mathrm{N}$ present as $\mathrm{NH}_{4}{ }_{\mathrm{f}}^{+} \mathrm{N}$ in main soil groups of Israel ranged between $1.8 \%$ and $78.6 \%$, with most of the values falling between $2 \%$ and $25 \%$. Highest values were obtained for the deepest horizons (Feigin and Yaalon 1974), where it ranged from $14 \%$ to $78 \%$ in British Caribbean soils (Rodrigues 1954), $3 \%$ to $44 \%$ in southern Ontario soils (Doram and Evans 1983), 16\% to 59\% in Vertisols and $13 \%$ to $31 \%$ in Cambisols in India (Sahrawat 1995), 21\% in Italian Fluvisols (Benedetti et al. 1996), and up to $85 \%$ in subsoils in the USA (Smith et al. 1994).

In a soil profile, the $\mathrm{NH}_{4}{ }^{+} \mathrm{f}-\mathrm{N}$ content as percent of the total $\mathrm{N}$ (inorganic plus organic) generally increases with soil depth (Black and Waring 1972; Doram and Evans 1983; Smith et al. 1994; Sahrawat 1995; Zhang et al. 2003) due to decreasing soil organic matter content. Fixation of $\mathrm{NH}_{4}{ }^{+}$in soil organic matter is negligible (Kowalenko and Cameron 1976). Contents of $\mathrm{NH}_{4}^{+} \mathrm{f}-\mathrm{N}$ in 24 soils from Queensland (Australia) averaged $4 \%$ of total $\mathrm{N}$ in surface soil and 6.4\% for subsoils (Black and Waring 1972). The magnitude of increase with depth was much higher in soils from southwestern Saskatchewan where it ranged from $7 \%$ of the total $\mathrm{N}$ in the surface soil to $58 \%$ in $120 \mathrm{~cm}$ depth (Hinman 1964). In Spanish soils, it ranged from $21 \%$ to $33 \%$ in the surface layers and $30 \%$ to $83 \%$ in subsoils with illite as the dominant clay mineral (Moyano and Gallardo 1988).

Yaalon and Feigin (1970) found that illite contains approximately $600 \mathrm{mg} \mathrm{N} \mathrm{kg}^{-1}$ illite, whereas montmorillonite contains small and kaolinite clays only negligible amounts. In mixed soil clays, the $\mathrm{NH}_{4}{ }^{+} \mathrm{f}-\mathrm{N}$ level is determined by the quantity of illite (Feigin and Yaalon 1974) and illite plus vermiculite (Sparks et al. 1979; Doram and Evans 1983), respectively. In contrast to the above results, Bajwa (1985) in a comparative study on fixation of $\mathrm{NH}_{4}^{+}$and $\mathrm{K}^{+}$in wetland rice soils found that in five soil clays, montmorillonitic clay fixed the maximum of the added $\mathrm{NH}_{4}{ }^{+}(98 \%)$ followed by vermiculite (88\%) and least $(34 \%)$ in clay containing hydrous mica, chlorite, and halloysite. On the other hand, montmorillonite, contrary to the other clay minerals, had no capacity for fixing $\mathrm{K}^{+}$. The overall capacity for fixation of monovalent cations $\left(\mathrm{K}^{+}\right.$plus $\mathrm{NH}_{4}{ }^{+}$) may therefore be greater for vermiculite compared to montmorillonite.

Influencing factors

The content of $\mathrm{NH}_{4}{ }_{\mathrm{f}}^{+}$and the capacity of soils to fix $\mathrm{NH}_{4}{ }^{+}$ is related to parent material (Table 1), texture (Baethgen and Alley 1987), clay content (Opuwaribo and Odu 1974; Sowden et al. 1978; Moyano and Gallardo 1988; Juang 1990), clay mineral composition (Feigin and Yaalon 1974; Sparks et al. 1979; Doram and Evans 1983; Niederbudde 1983), the K concentration in soil solution, the degree of $\mathrm{K}$ saturation of the exchange complex of the soil colloids and 
K saturation of the interlayers of 2:1 clay minerals (Hinman 1966; Doram and Evans 1983), and soil moisture conditions (Black and Waring 1972). Allison et al. (1953a) showed that vermiculite and illite have the greatest capacity to fix $\mathrm{NH}_{4}{ }^{+}$, while montmorillonite fixed less $\mathrm{NH}_{4}{ }_{\mathrm{f}}^{+}$and held it less tenaciously. Said (1973) reported that soils from Sudan with montmorillonite as the dominant clay mineral contained only small amounts of $\mathrm{NH}_{4}{ }^{+}{ }^{-} \mathrm{N}$ ranging between 30 and $60 \mathrm{~kg} \mathrm{~N} \mathrm{~kg}^{-1}$ soil. As compared to montmorillonite, beidelite is a high fixing smectite, due to the isomorphic substitution in the tetrahedral layer (Feigenbaum et al. 1994). Kaolinites, belonging to the $1: 1$ type of clay minerals, are not able to bind $\mathrm{NH}_{4}{ }^{+}$ions in their interlayers because hydrogen bonds which join the interlayers allow only very little dilatation of the narrow interlayer space (Mela Mela 1962).

In addition to clay minerals, the silt fraction has also been reported to bind $\mathrm{NH}_{4}{ }^{+}-\mathrm{N}$ in a non-exchangeable form. For example, in loess soils of central Europe, about only $65 \%$ of the $\mathrm{NH}_{4}^{+} \mathrm{f}^{-} \mathrm{N}$ is interlayer ammonium (Niederbudde and Friedrich 1984), while the rest is found in the silt fraction. The content of $\mathrm{NH}_{4}{ }^{+} \mathrm{f}-\mathrm{N}$ in the clay and silt ranged from 255 to $430 \mathrm{mg} \mathrm{N} \mathrm{kg}^{-1}$ and from 72 to $166 \mathrm{mg} \mathrm{N} \mathrm{kg}^{-1}$, respectively (Jensen et al. 1989). In a Canadian soil with 37\% clay, Kowalenko and Ross (1980) found similar amounts of $\mathrm{NH}_{4}{ }^{+}-\mathrm{N}$ for the clay and the silt fraction. In different primary minerals, the content of $\mathrm{NH}_{4}{ }^{+} \mathrm{f}$ - $\mathrm{N}$ has been reported to vary between nil in quartz to $266 \mathrm{mg} \mathrm{kg}^{-1}$ in biotite (Wlotzka 1961).

Some studies have demonstrated that the $\mathrm{NH}_{4}{ }^{+}$fixation capacity strongly depended on the degree of $\mathrm{K}$ saturation of the interlayers of the $2: 1$ clay minerals. If the $K$ content of a soil is high, it can be expected that the interlayer space will also be saturated with potassium (Scherer 1982) and to a smaller extend with $\mathrm{NH}_{4}{ }^{+}$ions (Petersburgsky and Smirnov 1966). As a result of competition for fixation sites, the presence of $\mathrm{NH}_{4}{ }^{+}$or $\mathrm{K}^{+}$may alter both fixation and release of these cations. In several studies, addition of $\mathrm{K}^{+}$prior to $\mathrm{NH}_{4}{ }^{+}$depressed $\mathrm{NH}_{4}{ }^{+}$fixation (Stanford and Pierre 1947; Nommik and Vahtras 1982), and addition of $\mathrm{NH}_{4}{ }^{+}$prior to or at the same time as $\mathrm{K}^{+}$reduced $\mathrm{K}^{+}$fixation (Aquaye and MacLean 1966; Bartlett and Simpson 1967). Contrarily, Drury et al. (1989) found that $\mathrm{K}^{+}$pre-addition did not block subsequent $\mathrm{NH}_{4}^{+}$fixation and the presence of $\mathrm{K}^{+}$induced greater $\mathrm{NH}_{4}^{+}$fixation (Chen et al. 1989). This is in agreement with the study by Bajwa (1985) in that the sequence in which $\mathrm{NH}_{4}^{+}$and $\mathrm{K}^{+}$were applied did not appear to affect the relative amounts that were fixed.

Application of $\mathrm{NH}_{4}{ }^{+}$-containing fertilizers may result in fixation of the added $\mathrm{NH}_{4}{ }^{+}$. However, the amount fixed is not directly proportional to the amount of fertilizer $\mathrm{N}$ added (Liang and MacKenzie 1994). Fixation is usually fast and occurs within the first few hours after fertilizer application.
The fixation rate is controlled mainly by ion diffusion and declines with time until the equilibrium point is approached (Nommik 1965). In experiments under laboratory conditions, Kowalenko and Cameron (1976) found that 50\% of added $\mathrm{NH}_{4}^{+}$was fixed within a short period of time, while in a field experiment, Kowalenko (1978) found that $59 \%$ of $152 \mathrm{~kg} \mathrm{~N} \mathrm{ha}^{-1}$ added as $\left(\mathrm{NH}_{4}\right)_{2} \mathrm{SO}_{4}$ was fixed within a few minutes after addition. In some soils of eastern Canada, more than $40 \%$ of the added $\mathrm{NH}_{4}^{+}$was fixed in less than $2 \mathrm{~h}$ and further fixation was negligible (Sowden et al. 1978). According to Chantigny et al. (2004), the highest fixation of $\mathrm{NH}_{4}^{+}$by clay minerals occurred within the first day and was greater in the clay soil ( $34 \%$ of applied $\left.{ }^{15} \mathrm{NH}_{4}-\mathrm{N}\right)$ than in the sandy soil $(11 \%)$. In studies with ${ }^{15} \mathrm{~N}$-labeled $\mathrm{NH}_{4}^{+} 18 \%$ to $23 \%$ of the applied ${ }^{15} \mathrm{NH}_{4}^{+}$was fixed after a 15-day incubation in soils with high contents of vermiculite (Drury et al. 1989).

The amount of added $\mathrm{NH}_{4}{ }^{+}$fixed depends on the $\mathrm{NH}_{4}{ }^{+}-$ fixing capacity of the soil. The estimation of the $\mathrm{NH}_{4}^{+}$ fixation capacity of a soil involves treatment of the soil with excessive amounts of concentrated $\mathrm{NH}_{4}{ }^{+}$solution in order to achieve complete saturation of the fixing minerals with $\mathrm{NH}_{4}{ }^{+}$(Nommik and Vahtras 1982) before estimation of the fixed $\mathrm{NH}_{4}{ }^{+}$by one of the methods described above. In a Gleysol with high $\mathrm{NH}_{4}{ }^{+}$-fixing capacity, Fischer et al. (1981) found that $47 \%$ of added ${ }^{15} \mathrm{~N}$ were fixed, whereas in a Histosol with very low $\mathrm{NH}_{4}{ }^{+}$fixation capacity, only $7 \%$ of the added $\mathrm{NH}_{4}^{+}$entered the interlayers of the clay minerals. Rider et al. (2005) focusing on the occurrence of $\mathrm{NH}_{4}{ }^{+}$fixation on a decomposed granitic substrate showed that the fixation capacities of these sandy saprolites are significant. At field loading rates equivalent to less than $300 \mathrm{~kg} \mathrm{NH}_{4}^{+}-\mathrm{N} \mathrm{ha}^{-1} 36 \%$ to $42 \%$ of the added $\mathrm{N}$ became unavailable to plants due to interlayer collapse and fixation. Ammonium fixation did not vary significantly in relation to substrate weathering class in these samples.

According to Allison et al. (1953a), soil moisture can reduce $\mathrm{NH}_{4}{ }^{+}$fixation as clay minerals are expanded under wet conditions. However, in dry soils, the interlayer space is reduced and $\mathrm{NH}_{4}{ }^{+}$fixation also increases. According to Osborne (1976b), $\mathrm{NH}_{4}{ }^{+}$fixation was reduced by $25 \%$ in a clay soil moistened to $60 \%$ of the maximum water holding capacity as compared with the dry soil. Also, Gouveia and Eudoxie (2007) found a lower $\mathrm{NH}_{4}{ }^{+}$fixation in wet soils. However, investigations in flooded rice soils yielded contradictory results. Some authors (Keerthisinghe et al. 1984; Chen et al. 1987a) observed that $\mathrm{NH}_{4}{ }^{+}$fixation in paddy soils was significantly increased as a consequence of flooding, while others (Williams et al. 1968; Chen et al. 1987b) stated that $\mathrm{NH}_{4}^{+}$fixation was less pronounced under flooded compared to non-flooded conditions. Schneiders and Scherer (1996) observed an increasing concentration of $\mathrm{NH}_{4}{ }^{+} \mathrm{f}-\mathrm{N}$ after flooding, which was closely 
related to the declining redox potential $\left(E_{\mathrm{h}}\right)$. Therefore, $E_{\mathrm{h}}$ may have an important effect on the fate of $\mathrm{NH}_{4}{ }^{+}$in paddy soils (Zhang and Scherer 1999). At a low $E_{\mathrm{h}}$, the octahedral $\mathrm{Fe}^{3+}$ in the clay minerals is assumed to be reduced, resulting in a higher negative charge of the unit cell and therefore a higher Coulombic attraction between the interlayer cations and the silicate layers (Stucki et al. 1984). This increasing $\mathrm{NH}_{4}^{+}$fixation can be an option for building an available $\mathrm{N}$ pool in paddy soils to minimize $\mathrm{N}$ losses into the environment (Liu et al. 2008). A further prerequisite for the pronounced $\mathrm{NH}_{4}{ }^{+}$fixation in flooded soils is the microbial reduction of $\mathrm{Fe}^{3+}$, followed by the dissolution of $\mathrm{Fe}$ oxides coated on the surface of clay minerals at a low $E_{\mathrm{h}}$, promoting the diffusion of $\mathrm{NH}_{4}{ }^{+}$ions into the interlayers of the clay minerals (Scherer and Zhang 1999). Because of the reversible oxidation and reduction of Fe oxides in paddy soils, this mechanism may be of special importance for fixation of $\mathrm{NH}_{4}{ }^{+}$(Zhang and Scherer 2000; Scherer and Zhang 2002). Figure 1 shows the relationship between the contents of $\mathrm{NH}_{4}^{+}{ }_{\mathrm{f}}^{-} \mathrm{N}$ and clay-bound $\mathrm{Fe}^{2+}$ in paddy soils and clay minerals.

\section{Availability of fixed $\mathrm{NH}_{4}{ }^{+}$to plants and microflora}

Fixation and release of $\mathrm{NH}_{4}^{+}{ }^{+}-\mathrm{N}$ is dependent upon chemical equilibria between the amounts of $\mathrm{NH}_{4}^{+}$, exchangeable $\mathrm{NH}_{4}{ }^{+}$and $\mathrm{NH}_{4}{ }^{+}$in soil solution (Nommik and Vahtras 1982),

$$
\left(\mathrm{NH}_{4}{ }_{\mathrm{s}}\right) \leftrightarrow\left(\mathrm{NH}_{4}{ }_{\mathrm{e}}\right) \leftrightarrow\left(\mathrm{NH}_{4}{ }_{\mathrm{f}}\right)
$$

where $\mathrm{NH}_{4}{ }_{\mathrm{s}}$ denotes ammonium in the soil solution and $\mathrm{NH}_{4}{ }_{\mathrm{e}}^{+}$and $\mathrm{NH}_{4}{ }_{\mathrm{f}}$ are exchangeable and fixed ions,

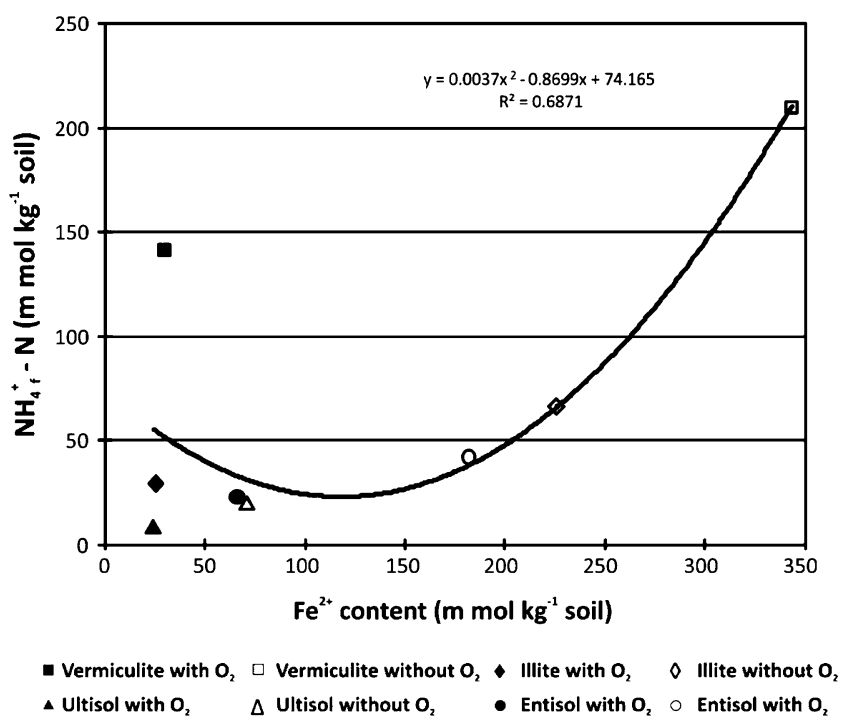

Fig. 1 Relationship between $\mathrm{NH}_{4}{ }^{+} \mathrm{f}^{-} \mathrm{N}$ and $\mathrm{Fe}^{2+}$ in soils and clay minerals (source: Scherer and Zhang 2002) respectively. However, results from several studies indicate that there is no equilibrium between exchangeable and fixed $\mathrm{NH}_{4}{ }^{+}$. Because $\mathrm{NH}_{4}{ }^{+}$and $\mathrm{K}^{+}$compete for the same binding sites, Nommik (1957) suggested that the sum of $\mathrm{NH}_{4}{ }^{+}$and $\mathrm{K}^{+}$rather than $\mathrm{NH}_{4}{ }^{+}$alone should be introduced into the equilibrium equation. Steffens and Sparks (1997) described the kinetics of $\mathrm{NH}_{4}{ }^{+} \mathrm{f}$ - $\mathrm{N}$ release from soil using the Elovich model. This model is empirical, and the process is assumed to be diffusion controlled. With decreasing $\mathrm{NH}_{4}{ }^{+}$concentration in soil solution, $\mathrm{NH}_{4}{ }^{+}$ions diffuse from clay mineral interlayers. Therefore, factors such as fertilizer $\mathrm{N}$ application, plant cover, soil organic matter, microflora, clay content, and clay mineral composition that affect concentration of $\mathrm{NH}_{4}{ }^{+}$in soil solution may promote either release or fixation of $\mathrm{NH}_{4}^{+}$. Because of methodological limitations (such as proper separation of recently fixed $\mathrm{NH}_{4}{ }^{+}$from native $\mathrm{NH}_{4}{ }_{\mathrm{f}}$ ) and the involvement of several factors and processes influencing soil $\mathrm{N}$ dynamics, it is still difficult to describe the dynamics of fixed $\mathrm{NH}_{4}{ }^{+}$especially under field conditions.

Plant availability

Investigations focusing on the availability of $\mathrm{NH}_{4}{ }^{+} \mathrm{f}$ - for crops have been reported with conflicting results. While early investigations of Legg and Allison (1959) and Black and Waring (1972) found that this $\mathrm{N}$ fraction plays a minor role for the $\mathrm{N}$ nutrition of plants, Norman and Gilmour (1987) estimated that the amounts of fertilizer-derived $\mathrm{NH}_{4}{ }^{+} \mathrm{f}-\mathrm{N}$ available to ryegrass ranged from $35 \%$ to $72 \%$. As percentage of total $\mathrm{NH}_{4}{ }^{+} \mathrm{f}-\mathrm{N}$, the release of this fraction ranged from $4 \%$ to $25 \%$ in different soils (Osborne 1976b; Smith et al. 1994; Steffens and Sparks 1997). According to Smith et al. (1994), only $8 \%$ of $\mathrm{NH}_{4}{ }^{+} \mathrm{f}-\mathrm{N}$ were released on average from the surface layers of a number of US soils. In a Luvisol derived from loess, up to $250 \mathrm{~kg} \mathrm{NH}_{4}^{+} \mathrm{f}^{-} \mathrm{N} \mathrm{ha}{ }^{-1}$ were released during a growing season of annual crops (oats and winter wheat; Van Praag et al. 1980). According to Baethgen and Alley (1987), $\mathrm{NH}_{4}{ }^{+}{ }^{-} \mathrm{N}$ contributed significantly to $\mathrm{N}$ taken up by wheat grown in the greenhouse.

Various plant species influence the $\mathrm{NH}_{4}{ }^{+}$f pool through different mechanisms. Plants can take up soluble or exchangeable $\mathrm{NH}_{4}^{+}$in the vicinity of $\mathrm{NH}_{4}{ }^{+}$-fixing clays and thus promote diffusion of ions out of the interlayers. Plant roots can also affect the $\mathrm{NH}_{4}{ }_{\mathrm{f}}$ pool indirectly by releasing exudates that promote the activity of the soil microflora and microbial $\mathrm{N}$ uptake (Marschner 1995). The magnitude of $\mathrm{NH}_{4}{ }^{+}-\mathrm{N}$ release strongly depends on the length of crop growth period and plant density (Saha and Mukhopadhyay 1986).

Most of the differences in $\mathrm{NH}_{4}{ }^{+} \mathrm{N}$ release can probably be attributed to both the variable pool sizes of "native fixed $\mathrm{NH}_{4}{ }^{+}$" and "recently fixed $\mathrm{NH}_{4}{ }^{+}$" and the lack of methods 
available to separate these fractions adequately. The recently fixed $\mathrm{NH}_{4}^{+}$is mainly derived from mineral $\mathrm{N}$ fertilizers (Chen et al. 1989; Smith et al. 1994), but it may also originate from mineralization of soil organic matter (Nieder et al. 1995b). Dou and Steffens (1995) found that $90 \%$ to $95 \%$ of recently fixed ${ }^{15} \mathrm{NH}_{4}{ }^{+}$was released during a 14-week period in the soil planted with perennial ryegrass (Lolium perenne L.) under greenhouse conditions. Under field conditions, $66 \%$ of the recently fixed $\mathrm{NH}_{4}{ }^{+}-\mathrm{N}$ was released in the first 86 days after fixation and the remaining was strongly fixed over the next 426 days (Kowalenko 1978). Apparently, recently fixed $\mathrm{NH}_{4}{ }^{+}$resulting from fertilizer application is more available to plants than native $\mathrm{NH}_{4}{ }^{+}$, which is more tightly held (Black and Waring 1972; Kudeyarov 1981; Mengel and Scherer 1981; Keerthisinghe et al. 1984). Probably native $\mathrm{NH}_{4}{ }^{+} \mathrm{f}-\mathrm{N}$ is trapped in the center of the interlayers to a higher degree, while recently fixed $\mathrm{NH}_{4}{ }^{+}$ions are largely retained in the peripheral zone of the interlayers (Nommik and Vahtras 1982). Differences in clay mineralogy and $\mathrm{K}$ saturation of the minerals also influence the release of $\mathrm{NH}_{4}{ }^{+} \mathrm{f}-\mathrm{N}$. Mengel et al. (1990) found that only soils containing vermiculite and low contents of exchangeable $\mathrm{K}^{+}$released significantly higher amounts of $\mathrm{NH}_{4}{ }_{\mathrm{f}}$ as compared to soils with no vermiculite and high percentage of $\mathrm{K}^{+}$saturation of the clay minerals. In a pot experiment of Scherer (1985) with ryegrass, where $\mathrm{NH}_{4}^{+}$was added before and after the application of $\mathrm{K}^{+}$, respectively or simultaneously, the content of $\mathrm{NH}_{4}{ }_{\mathrm{f}}^{+}$was the highest, when $\mathrm{NH}_{4}{ }^{+}$was applied before $\mathrm{K}$ and lowest when $\mathrm{K}$ was applied first (Table 2).

Scherer (1987) further reported that in field plots heavily dressed with $\mathrm{K}^{+}$, no release of $\mathrm{NH}_{4}{ }^{+}{ }_{\mathrm{f}}^{-} \mathrm{N}$ was found, whereas in plots with low $\mathrm{K}^{+}$application, considerable amounts of $\mathrm{NH}_{4}{ }^{+}$were released. In analogy to these findings, adsorption/desorption experiments (isotherm studies in soils containing vermiculite and illite) in a binary $\left(\mathrm{Ca}^{2+} / \mathrm{NH}_{4}{ }^{+}\right)$ and a ternary $\left(\mathrm{Ca}^{2+} / \mathrm{K}^{+} / \mathrm{NH}_{4}{ }^{+}\right)$cation system (Lumbanraja and Evangelou 1994) revealed that $\mathrm{NH}_{4}{ }^{+}$desorption decreased in the presence of solution $\mathrm{K}^{+}$(ternary) relative to that in the absence of $\mathrm{K}^{+}$(binary). Fixation of $\mathrm{K}^{+}$in the presence of solution $\mathrm{NH}_{4}^{+}$was suppressed as compared to

Table 2 Influence of the application time of $\mathrm{K}^{+}$on the content of $\mathrm{NH}_{4}{ }^{+}{ }^{-} \mathrm{N}$ and exchangeable $\mathrm{K}^{+}$(source: Scherer 1985)

\begin{tabular}{lll}
\hline \multirow{2}{*}{ Treatment } & \multicolumn{2}{l}{ Mean $\pm \mathrm{SD}\left(\mathrm{mg} \mathrm{kg}^{-1}\right.$ soil $)$} \\
\cline { 2 - 3 } & $\mathrm{NH}_{4}^{+} \mathrm{f}^{-} \mathrm{N}$ & Exchangeable $\mathrm{K}^{+}$ \\
\hline $\mathrm{K}^{+}$before $\mathrm{NH}_{4}^{+}$ & $231 \pm 3.7$ & $142 \pm 4.6$ \\
$\mathrm{~K}^{+}$and $\mathrm{NH}_{4}^{+}$simultaneously & $246 \pm 4.7$ & $204 \pm 2.4$ \\
$\mathrm{~K}^{+}$following $\mathrm{NH}_{4}^{+}$ & $252 \pm 4.0$ & $214 \pm 4.5$ \\
LSD 5\% & 5 & 8 \\
\hline
\end{tabular}

that in the absence of $\mathrm{NH}_{4}^{+}$. Contrarily, $\mathrm{NH}_{4}^{+}$fixation was enhanced in the presence of solution $\mathrm{K}^{+}$relative to that in the absence of $\mathrm{K}^{+}$. Thus, contrary to common belief, the two ions do not behave as true analogs with respect to fixation reactions.

The mechanisms regulating the release and subsequent plant uptake are still not completely understood. According to Mengel et al. (1990) and Scherer and Ahrens (1994; 1996), plant roots deplete the $\mathrm{NH}_{4}{ }^{+}$concentration of the soil solution in the rhizosphere and, therefore, promote the release of $\mathrm{NH}_{4}^{+}$f (Fig. 2).

Further, the relative amounts of $\mathrm{NH}_{4}^{+}$and $\mathrm{K}^{+}$in soil solution govern the rate of release of $\mathrm{NH}_{4}{ }^{+}$from interlayer positions (Welch and Scott 1960). Under field conditions, continuous uptake of $\mathrm{NH}_{4}^{+}$and $\mathrm{K}^{+}$ions by roots may reduce concentrations of both ions and therefore, diminish the blocking effect of $\mathrm{K}^{+}$on the release of $\mathrm{NH}_{4}^{+}$.

Availability to microflora

Early work concerning the influence of the soil microflora on the mobilization of $\mathrm{NH}_{4}{ }_{\mathrm{f}}^{+}$suggested only a minor role for the microflora (Allison et al. 1953b). While only between $13 \%$ and $28 \%$ of the $\mathrm{NH}_{4}{ }^{+}$f was oxidized, up to almost $80 \%$ of the exchangeable $\mathrm{NH}_{4}{ }^{+}$was nitrified (Bower 1950). However, according to later studies heterotrophic microorganisms can rapidly assimilate $\mathrm{NH}_{4}{ }^{+}$from the nonexchangeable pool (Nommik and Vahtras 1982; Drury and Beauchamp 1991) and therefore favor the release of $\mathrm{NH}_{4}^{+}$ ions from the clay minerals (Jensen et al. 1989). In incubation experiments involving ${ }^{15} \mathrm{~N}$-labeled $\mathrm{NH}_{4}^{+} \mathrm{f}$, the addition of an easily available $\mathrm{C}$ substrate favored the mobilization of this $\mathrm{N}$ fraction by heterotrophic microorganisms

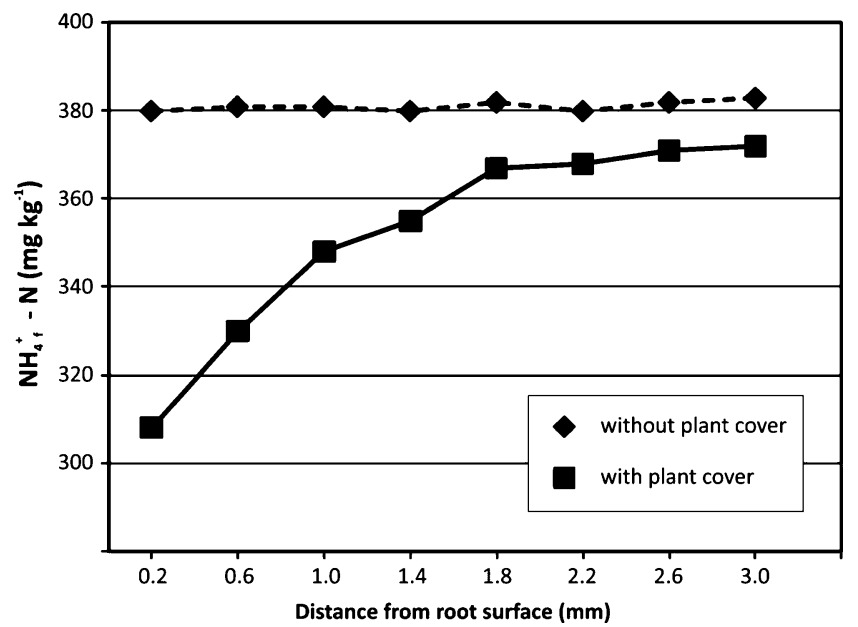

Fig. 2 Depletion profile of $\mathrm{NH}_{4}^{+}{ }_{\mathrm{f}}^{-} \mathrm{N}$ in the rhizosphere of oilseed rape in a soil with high amount of expandable clay minerals (57\% clay and $17 \%$ of smectites and vermiculite in the clay fraction; source: Scherer and Ahrens 1996) 
(Breitenbeck and Paramasivam 1995), so that between 64\% and $96 \%$ of non-exchangeable ${ }^{15} \mathrm{NH}_{4}{ }^{+}$was released. Different plant species produce root exudates with different quantity and quality which can differently affect activity and composition of the soil microflora (Nannipieri et al. 1999). Moreover, the release of $\mathrm{NH}_{4}{ }_{\mathrm{f}} \mathrm{can}$ be promoted by nitrification which causes changes in $\mathrm{NH}_{4}{ }^{+}$equilibria (Green et al. 1994). Fumigation to inhibit soil biological activity as well as the application of a nitrification inhibitor (nitrapyrin) hampered the release of $\mathrm{NH}_{4}{ }_{\mathrm{f}} \mathrm{f}$ (Aulakh and Rennie 1984). According to Tang et al. (2008), the stimulated assimilation of ammonium after glucose addition creates a steep concentration gradient between the $\mathrm{NH}_{4}{ }^{+}$concentration of the soil solution and the $\mathrm{NH}_{4}{ }_{\mathrm{f}}^{+}$and thus promoting the release of $\mathrm{NH}_{4}{ }^{+}$from the clay mineral interlayers. The results also show that $\mathrm{K}$ added simultaneously with the carbon source impeded the release of $\mathrm{NH}_{4}{ }^{+}$ions, which may be due to the blocking effect of $\mathrm{K}^{+}$ions.

Results from field experiments during the cereal growing season (Nieder et al. 1995a, b, 1996) suggest that the dynamic microflora, due to its influence on the equilibria between the amounts of different $\mathrm{N}$ fractions, may exert a great influence on the dynamics of $\mathrm{NH}_{4}{ }^{+}$. The minima of mineral $\mathrm{N}$ contents (due to plant and microbial $\mathrm{N}$ uptake) and correspondingly, of $\mathrm{NH}_{4}{ }_{\mathrm{f}} \mathrm{f}$ contents, occurred during phases of increasing microbial biomass under a C-supplying plant cover, proving that the heterotrophic microflora, as a consequence of the increased microbial $\mathrm{N}$ uptake, favor the release of $\mathrm{NH}_{4}^{+}{ }_{\mathrm{f}}^{+}$(Fig. 3).

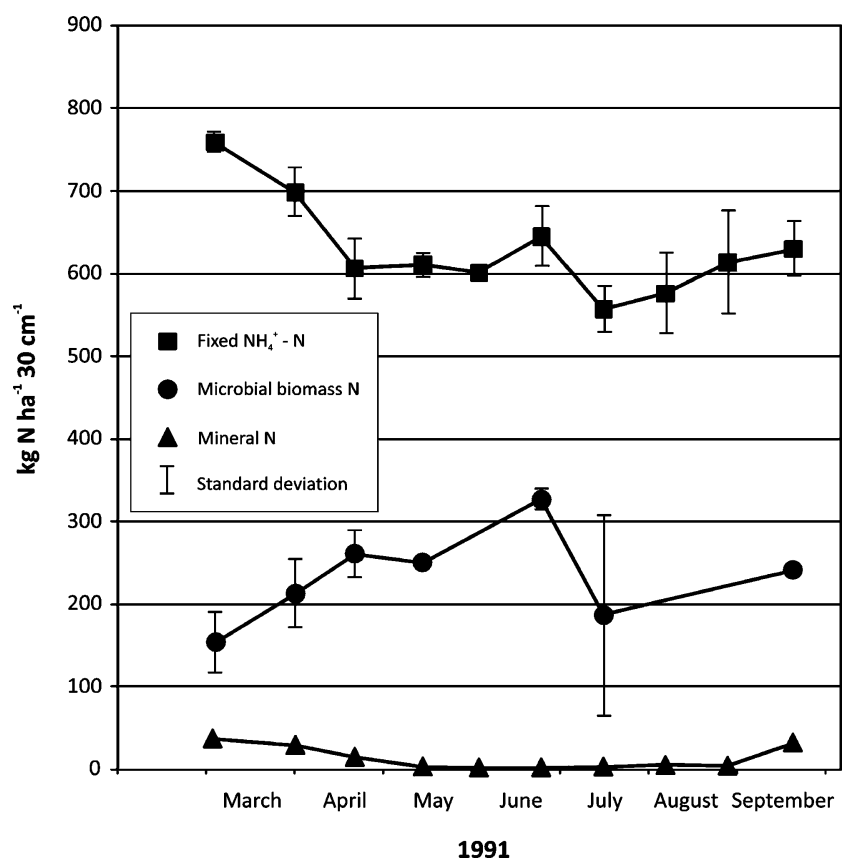

Fig. 3 Dynamics of $\mathrm{NH}_{4}{ }^{+} \mathrm{f}-\mathrm{N}$, microbial biomass $\mathrm{N}$, and mineral $\mathrm{N}$ $\left(\mathrm{NH}_{4}{ }^{+}-\mathrm{N}\right.$ plus $\left.\mathrm{NO}_{3}{ }^{-}-\mathrm{N}\right)$ in a Luvisol $\mathrm{A}_{\mathrm{p}}$ horizon under winter wheat (source: compiled from Nieder et al. 1995a)

\section{Seasonal dynamics of $\mathrm{NH}_{4}^{+} \mathrm{f}$}

The pattern of seasonal changes in the contents of $\mathrm{NH}_{4}{ }_{\mathrm{f}}^{+}$in arable soils is well-known (Kowalenko and Cameron 1976; Sowden 1976; Kowalenko and Ross 1980; Li et al. 1990a, b; Drury and Beauchamp 1991; Green et al. 1994). Mengel and Scherer (1981), investigating the dynamics of this N fraction in a Fluvisol during the growing season, found that the content of $\mathrm{NH}_{4}{ }^{+} \mathrm{f}$ declined in the top $60 \mathrm{~cm}$ from February to May (Fig. 4).

In the deeper soil layer $(60-90 \mathrm{~cm}$ depth), depletion was observed from May to July, which was in accordance with the root growth of spring oats. At the end of the growing season, the clay mineral interlayers were refilled and almost the same content was attained as in spring. Li et al. $(1990 \mathrm{a}, \mathrm{b})$ have shown a significant decrease of $\mathrm{NH}_{4}{ }_{\mathrm{f}} \mathrm{in}$ upper soil layers in March and in deeper soil layers during April. In field experiments on loess soils, Nieder et al. (1996) observed a significant correlation between the time course of $\mathrm{NH}_{4}^{+} \mathrm{f}$ and mineral $\mathrm{N}$ in soil solution. The refixation of $\mathrm{NH}_{4}^{+}$in autumn may be mainly due to increased mineralization after the harvest of annual crops. Table 3 reflects this pattern (ranges of $\mathrm{NH}_{4}{ }^{+}$fixation in spring, $\mathrm{NH}_{4}^{+}$release in summer and $\mathrm{NH}_{4}^{+}$refixation in autumn) with results (according to pool size or ${ }^{15} \mathrm{~N}$ method, respectively) drawn from different studies, grouped according to upland (silty and clayey) and paddy soils.

In most of studies presented in Table 3, the $\mathrm{NH}_{4}{ }^{+}-\mathrm{N}$ fixation in spring, occurring probably as a consequence of (mineral) fertilizer application at the beginning of the growth period, was not determined. The amounts of $\mathrm{NH}_{4}{ }^{+} \mathrm{N}$ released in summer vary greatly within the groups of silty $\left(20-200 \mathrm{~kg} \mathrm{NH}_{4}^{+}-\mathrm{N} \mathrm{ha}^{-1} 30 \mathrm{~cm}^{-1}\right)$ as well as clayey (40-188 $\mathrm{kg} \mathrm{NH}_{4}^{+}-\mathrm{N} \mathrm{ha}^{-1} 30 \mathrm{~cm}^{-1}$ ) soils. Studies in which

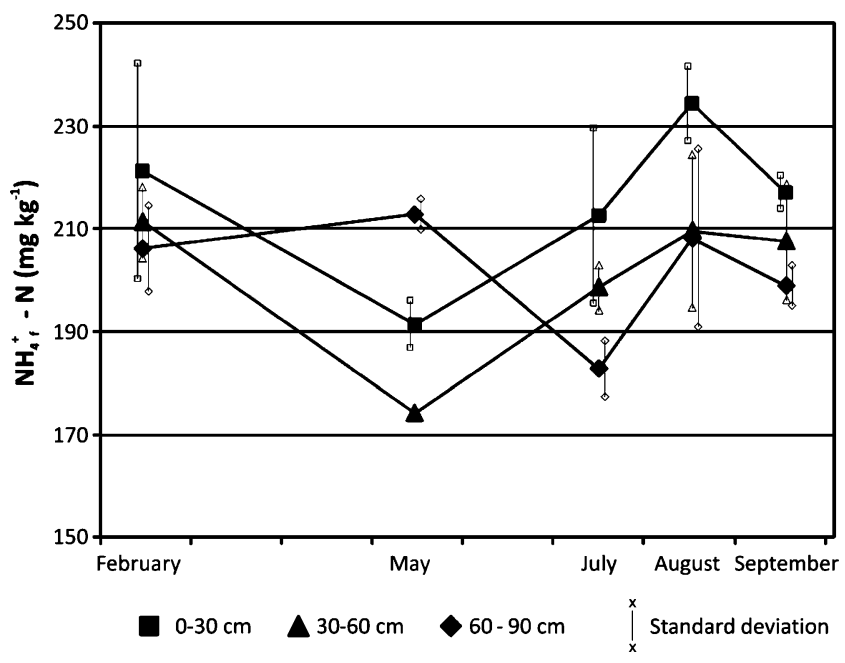

Fig. 4 Release of $\mathrm{NH}_{4}^{+}{ }^{-} \mathrm{N}$ in a Fluvisol during the growing season of spring oats (source: Mengel and Scherer 1981) 


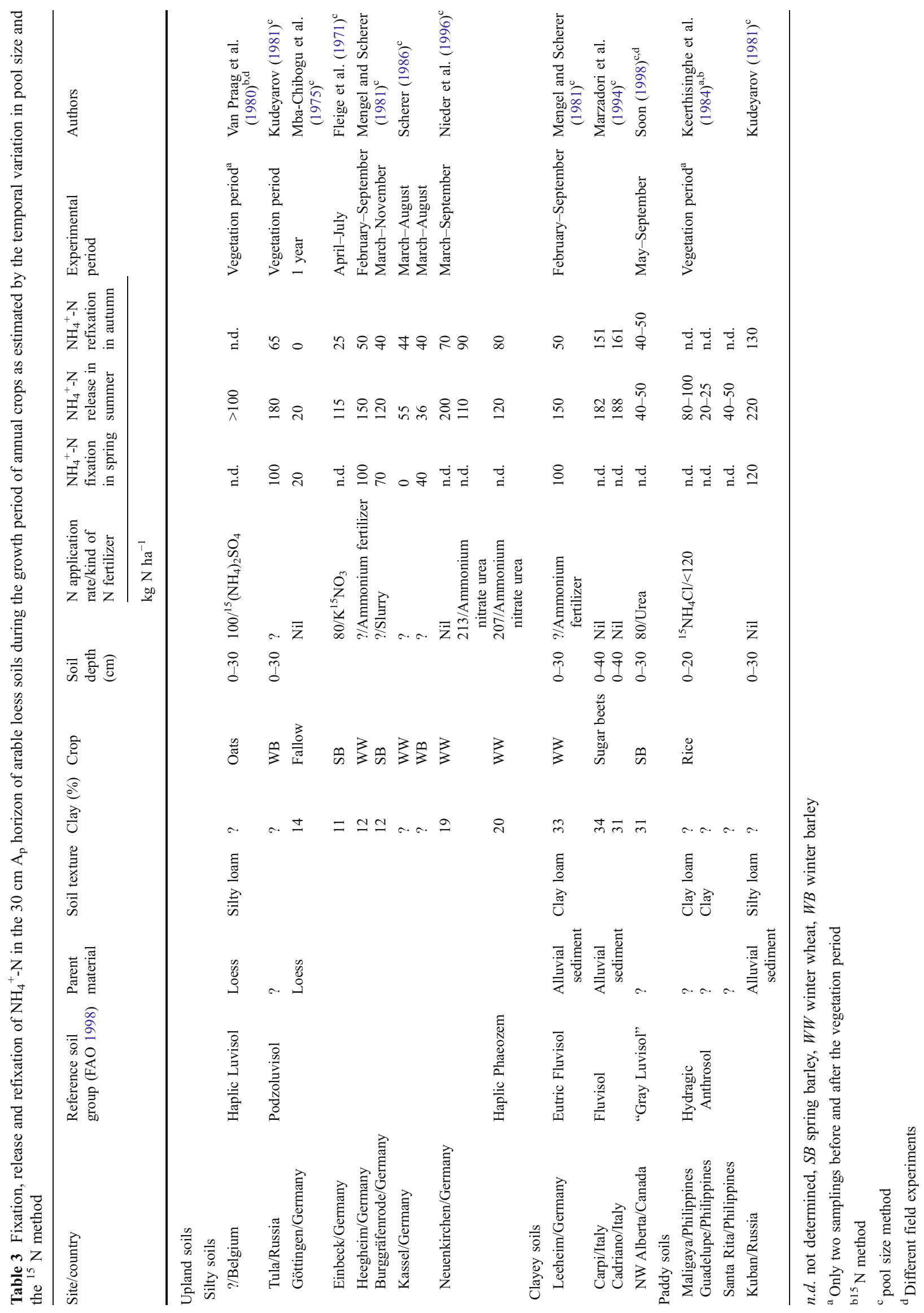


subsoils $(>30 \mathrm{~cm})$ were included indicate even higher amounts of $\mathrm{NH}_{4}^{+} \mathrm{f}^{-} \mathrm{N}$ release. For example, estimates were up to $250 \mathrm{~kg} \mathrm{NH}_{4}{ }^{+} \mathrm{f}-\mathrm{N}$ release to a soil depth of $70 \mathrm{~cm}$ in Belgium (Van Praag et al. 1980) and up to $350 \mathrm{~kg} \mathrm{NH}_{4}{ }^{+} \mathrm{f}-\mathrm{N}$ release to a soil depth of $75 \mathrm{~cm}$ in Germany (Mengel and Scherer 1981).

Although the total amounts of $\mathrm{NH}_{4}^{+} \mathrm{f}$ ("native" plus "recently fixed") are probably much higher in the clayey soils (clay contents $>30 \%$ ) compared to the silty soils (10$20 \%$ clay), the amounts of $\mathrm{NH}_{4}^{+} \mathrm{f}$ which are available in a growth period of annual crops seem to be in a similar order of magnitude (Table 3). This indicates a wider ratio of "native" to "recently fixed" $\mathrm{NH}_{4}{ }^{+}$in the clayey soils. The low values of $\mathrm{NH}_{4}{ }_{\mathrm{f}}^{+}$release presented in Table 3 can partly be attributed to the fact that the experimental plot was kept fallow (study by Mba-Chibogu et al. 1975) or that the experimental soil had a history of only moderate $\mathrm{N}$ fertilization (not more than $60 \mathrm{~kg} \mathrm{~N} \mathrm{ha}^{-1}$ year $^{-1}$ for 25 years prior to the initiation of the study) with a low yield level (study by Soon 1998). In contrast, soils with a high level of long-term $\mathrm{N}$ fertilizer application and a high yield level show a high temporal variation in the interlayer $\mathrm{NH}_{4}{ }^{+}$ concentration, especially on control plots with limited contents of mineral $\mathrm{N}$ (see plot with nil $\mathrm{N}$ application in the study by Nieder et al. 1996). Most field observations show that the amounts of $\mathrm{NH}_{4}{ }^{+}-\mathrm{N}$ refixed in autumn are commonly smaller compared to the amounts of $\mathrm{NH}_{4}{ }^{+}-\mathrm{N}$ which are fixed in spring minus the amounts of $\mathrm{NH}_{4}{ }^{+} \mathrm{f}$ released in summer. It is thus obvious that for replenishment of the plant-available $\mathrm{NH}_{4}{ }^{+}$f pool to levels that occur at the beginning of the growth periods, the preceding winter periods would additionally be required.

Fixation is usually faster than release of $\mathrm{NH}_{4}{ }^{+}$(Drury and Beauchamp 1991). Kowalenko and Cameron (1976) observed that more than one half of the added $\mathrm{NH}_{4}{ }^{+}-\mathrm{N}$ was fixed within 1.7 days, whereas the average daily release of $\mathrm{NH}_{4}{ }_{\mathrm{f}}^{+}$was 1.7 and $0.65 \mathrm{~kg} \mathrm{~N} \mathrm{ha}^{-1}$ between 19 June to 1 August 1974 and between 1 August to 13 September 1974, respectively (Kowalenko 1978). From the foregoing, it appears that while the native $\mathrm{NH}_{4}{ }_{\mathrm{f}}$ has no significance in the soil N dynamics (Mengel and Scherer 1981; Smith et al. 1994), the temporal changes in the content of recently fixed $\mathrm{NH}_{4}{ }^{+}$show that this fraction is actively involved in the $\mathrm{N}$ dynamics during the crop growth period. Added $\mathrm{NH}_{4}{ }^{+}$is quickly fixed by the clay minerals and later released slowly during the crop growth season due to increased crop demand with concomitant decrease in $\mathrm{NH}_{4}{ }^{+}$concentration in soil solution. Supply of C-containing root exudates by the plant enhances the activity of heterotrophic microorganisms which may promote the release of fixed $\mathrm{NH}_{4}{ }^{+}$.

The phenomenon of temporary fixation and release of added fertilizer $\mathrm{NH}_{4}^{+}$may contribute to retarding nitrification and thus to reducing $\mathrm{N}$ losses from the soil-plant system via $\mathrm{NO}_{3}{ }^{-}$leaching and denitrification $\left(\mathrm{N}_{2}, \mathrm{~N}_{2} \mathrm{O}\right)$. In the winter-humid temperate climate, it is generally observed that contents of $\mathrm{NH}_{4}^{+} \mathrm{f}$ reach their maximum during the winter period, when nitrate leaching occurs frequently. The extent of nitrate leaching may then partly depend on the $\mathrm{NH}_{4}{ }^{+}$fixation capacity of the soil. For example, the losses of added fertilizer $\mathrm{N}\left({ }^{15} \mathrm{NH}_{4}{ }^{+}\right)$were more than double in a Histosol with extremely low $\mathrm{NH}_{4}{ }^{+}$-fixing capacity as compared to that from a clay containing Gleysol with high fixing capacity (Fischer et al. 1981). Similarly, $\mathrm{NH}_{4}{ }^{+}-\mathrm{N}$ fixation by clay minerals may also contribute to reducing $\mathrm{NH}_{3}$ volatilization losses (Dou and Steffens 1995). It may, therefore, be argued that clay fixation of $\mathrm{NH}_{4}{ }^{+}$can provide a temporary sink for fertilizer $\mathrm{N}$ that subsequently acts as a source of $\mathrm{N}$ for plant uptake. Information on soil $\mathrm{NH}_{4}{ }^{+} \mathrm{-N}$ fixation capacity and its plant availability is necessary for developing efficient $\mathrm{N}$ fertilizer management programs.

Although the knowledge on the magnitude and the dynamics of $\mathrm{NH}_{4}{ }_{\mathrm{f}} \mathrm{f}$ has increased during the last few decades, there are still conflicting reports about the importance of $\mathrm{NH}_{4}{ }_{\mathrm{f}}$ for plants and microflora. This may be due to the fact that up to now, it is not possible to distinguish properly between native fixed (non-available) and recently fixed (plant-available) $\mathrm{NH}_{4}{ }^{+}$. As a consequence, the pool of plant-available $\mathrm{NH}_{4}{ }_{\mathrm{f}}^{+}$has hardly been integrated into models to describe the $\mathrm{N}$ dynamics of soils. Further research on methodological aspects is, therefore, required for both proper separation of recently fixed $\mathrm{NH}_{4}{ }^{+}$from native fixed $\mathrm{NH}_{4}^{+}$and modeling the kinetics of plant-available $\mathrm{NH}_{4}^{+}$f. This would be a basis for integrating the pool of recently fixed $\mathrm{NH}_{4}{ }^{+}$in fertilizer management programs.

Acknowledgments Dinesh K. Benbi is thankful to the Alexander von Humboldt-Stiftung, Jean-Paul-Straße 12, Bonn for a research fellowship.

Open Access This article is distributed under the terms of the Creative Commons Attribution Noncommercial License which permits any noncommercial use, distribution, and reproduction in any medium, provided the original author(s) and source are credited.

\section{References}

Allison FE, Doetsch JH, Roller EM (1951) Ammonium fixation and availability in Harpster clay loam. Soil Sci 72:181-200

Allison FE, Doetsch JH, Roller E (1953a) Availability of fixed ammonium in soils containing different clay minerals. Soil Sci $75: 373-381$

Allison FE, Roller EM, Doetsch JH (1953b) Ammonium fixation and availability in vermiculite. Soil Sci 75:173-180

Antisari VL, Sequi P (1988) Comparison of total nitrogen by four procedures and sequential determination of exchangeable ammonium, organic nitrogen and fixed ammonium in soil. Soil Sci Soc Am J 52:1020-1023

Antisari VL, Ciavatta C, Sequi P (1987) Determination of fixed ammonium in soil after treatment with hydrogen peroxide plus sodium pyrophosphate and sodium chloride. Agrochimica 31:563-566 
Aquaye DK, MacLean AJ (1966) Influence of form and mode of nitrogen fertilizer application on the availability of soil and fertilizer potassium. Can J Soil Sci 46:23-28

Aulakh MS, Rennie DA (1984) Transformations of fall-applied nitrogen-15 labelled fertilizers. Soil Sci Soc Am J 48:1184-1189

Axley JH, Legg JO (1960) Ammonium fixation in soils and the influence of potassium on nitrogen availability from nitrate and ammonium sources. Soil Sci 90:151-156

Baethgen WE, Alley MM (1987) Non-exchangeable ammonium nitrogen contribution to plant available nitrogen. Soil Sci Soc Am J 51:110-115

Bajwa MI (1985) Ammonium and potassium fixation by wetland rice soils. Pak J Agric Res 6:23-25

Barshad I (1951) Cation exchange in soils: I. Ammonium fixation and its relation to potassium fixation and to determination of ammonium exchange capacity. Soil Sci 72:361-371

Bartlett RJ, Simpson TJ (1967) Interaction of ammonium and potassium in a potassium-fixing soil. Soil Sci Soc Am Proc 31:219-222

Beese F (1986) Parameter des Stickstoffumsatzes in Ökosystemen mit Böden unterschiedlicher Acidität. Gött Bodenkdl Ber 90:344

Benedetti A, Antisari LV, Canali S, Gioacchini P, Sequi P (1996) Relationship between the fixed ammonium and the mineralization of the organic nitrogen in soil. In: Van Cleemput O, Hofman G, Vermoesen A (eds) Progress in nitrogen cycling studies. Kluwer, The Netherlands, pp 23-26

Black AS, Waring SA (1972) Ammonium fixation and availability in some cereal producing soils of Queensland. Aust J Soil Res 10:197-207

Bower CA (1950) Availability of ammonium fixed in a difficulty exchangeable from by soils of semiarid regions. Soil Sci Soc Am Proc 14:119-122

Breitenbeck GA, Paramasivam S (1995) Availability of ${ }^{15} \mathrm{~N}$-labeled non-exchangeable ammonium to soil microorganisms. Soil Sci 159:301-310

Bremner JM (1959) Determination of fixed ammonium in soils. J Agric Sci Camb 52:147-160

Bremner JM, Nelson DW, Silva A (1967) Comparison and evaluation of methods of determining fixed ammonium in soils. Soil Sci Soc Am Proc 31:466-472

Chantigny MH, Angers DA, Morvan T, Pomar C (2004) Dynamics of pig slurry nitrogen in soil and plant as determined with $\mathrm{N}-15$. Soil Sci Soc Am J 68:637-643

Chen R, Zhang J, Guo W, Chen W (1987a) N fertilizer (urea) topdressed on unsaturated soil and deep-placed using reflooding water. Int Rice Res News1 12:35-36

Chen SZ, Low PF, Roth CB (1987b) Relation between potassium fixation and oxidation state of octahedral iron. Soil Sci Soc Am J 51:82-86

Chen CC, Turner FT, Dixon JB (1989) Ammonium fixation by highcharge smectite in selected Texas Gulf Coast soils. Soil Sci Soc Am J 53:1035-1040

Cox AE, Joern BC, Roth CB (1996) Non-exchangeable ammonium and potassium determination in soils with modified sodium tetraphenylboron method. Soil Sci Soc Am J 60:114-120

Dhariwal APS, Stevenson FJ (1958) Determination of fixed ammonium in soils. Soil Sci 86:343-349

Dixit VK, Mir SU (1987) A comparative study of different methods of determining fixed ammonium in soils. Indian J Agric Chem 20:19-23

Doram DR, Evans LJ (1983) Native fixed ammonium and fixation of added ammonium in relation to clay mineralogy in some Ontario soils. Can J Soil Sci 63:631-639

Dou H, Steffens D (1995) Recovery of ${ }^{15} \mathrm{~N}$ labelled urea as affected by fixation of ammonium by clay minerals. Z Pflanzenernahr Bodenkd 158:351-354

Drury CF, Beauchamp EG (1991) Ammonium fixation, release, nitrification and immobilization in high- and low-fixing soils. Soil Sci Soc Am J 55:980-985
Drury CF, Beauchamp EG, Evans LJ (1989) Fixation and immobilization of recently applied ${ }^{15} \mathrm{NH}_{4}{ }^{+}$in selected Ontario and Quebec soils. Can J Soil Sci 69:391-400

Elmaci ÖL, Secer M, Erdemir O, Iqbal N (2002) Ammonium fxation properties of some arable soils from the Agean region of Turkey. Eur J Agron 17:199-208

FAO (1998) World reference base for soil resources, ISSS, ISRIC, FAO. World Soil Resources Report 84, Rome, FAO-UNESCO, FAO, pp. 88

Feigenbaum S, Hadas A, Sofer M, Molina JAE (1994) Clay-fixed ammonium as a source of available nitrogen. Soil Sci Soc Am J 58:980-985

Feigin A, Yaalon DH (1974) Non-exchangeable ammonium in soils of Israel and its relation to clay and parent material. J Soil Sci 25:384-397

Fischer WR, Pfanneberg T, Niederbudde EA, Medina R (1981) Transformation of ${ }^{15} \mathrm{~N}$-labelled ammonium in two soils differing in $\mathrm{NH}_{4}{ }^{+}$-fixing capacity. J Soil Sci 32:409-418

Fleige H, Meyer B (1975) Mineralisch fixiertes Ammonium in jungpleistozänen Sedimenten Norddeutschlands und ihren fossilen und holozänen Böden: Ein Indikator für litho- oder pedogenetische Prozesse und Herkünfte. Gött Bodenkdl Ber 34:315-328

Fleige H, Meyer B, Scholz H (1971) Bilanz und Umverteilung der Bindungsformen von Boden- und Dünger-Stickstoff in einer Acker-Parabraunerde aus Löß. Gött Bodenkdl Ber 18:39-86

Frye WW, Hutcheson TB (1981) Release of $\mathrm{NH}_{4}{ }^{+}$in soils by oven drying. Soil Sci Soc Am J 45:889-892

Gorlach E, Grywnowicz J (1988) Distribution of various nitrogen forms in the soil profile and their relationship with nitrogen taken up by plants. Pol J Soil Sci 21:43-49

Gouveia GA, Eudoxie GD (2007) Distribution of fertiliser N among fixed ammonium fractions as affected by moisture and fertiliser source and rate. Biol Fertil Soils 44:9-18

Green CJ, Blackmer AM, Yang NC (1994) Release of fixed ammonium during nitrification in soils. Soil Sci Soc Am J 58:1411-1415

Greenfield LG (1991) Fixed ammonium in Antarctic rocks and soil and a possible cause of underestimation. Soil Biol Biochem 23:397-399

Guo P-C, Bogring J, Scherer HW (1983) Verhalten von Dünger- $\mathrm{NH}_{4}{ }^{+}$ in Böden unterschiedlicher tonmineralischer Zusammensetzung. Z Pflanzenernahr Bodenkd 146:752-757

Hinman WC (1964) Fixed ammonium in some Saskatchewan soils. Can J Soil Sci 44:151-157

Hinman WC (1966) Ammonium fixation in relation to exchangeable $\mathrm{K}$ and organic matter content in two Saskatchewan soils. Can J Soil Sci 46:223-225

Jensen ES, Christensen BT, Sorensen LH (1989) Mineral-fixed ammonium in clay- and silt-size fractions of soils incubated with ${ }^{15} \mathrm{~N}$ ammoniumsulphate for five years. Biol Fertil Soils 8:298-302

Juang TC (1990) Ammonium fixation as affected by temperature and drying-wetting effect in Taiwan soils. Proc Natl Sci Counc Repub China Part B Life Sci 14:151-158

Juang TC, Wang MK, Chen HJ, Tan CC (2001) Ammonium fixation by surface soils and clays. Soil Sci 166:345-352

Keerthisinghe G, Mengel K, De Datta SK (1984) The release of nonexchangeable ammonium $\left({ }^{15} \mathrm{~N}\right.$ labelled) in wetland rice soils. Soil Sci Soc Am J 48:291-294

Kittrick JA (1966) Forces involved in ion fixation by vermiculite. Soil Sci Soc Am Proc 30:801-803

Kowalenko CG (1978) Nitrogen transformations and transport over 17 months in field fallow microplots using ${ }^{15}$ N. Can J Soil Sci 58:69-76

Kowalenko CG, Cameron DR (1976) Nitrogen transformations in an incubated soil as affected by combinations of moisture and temperature and adsorption-fixation of ammonium. Can J Soil Sci 56:63-70

Kowalenko CG, Ross GJ (1980) Studies on dynamics of recently clayfixed $\mathrm{NH}_{4}^{+}$using ${ }^{15} \mathrm{~N}$. Can J Soil Sci 60:61-70 
Kudeyarov VN (1981) Mobility of fixed ammonium in soil. In: Clark FE, Rosswall $\mathrm{T}$ (eds) Terrestrial nitrogen cycles. Ecol Bull (Stockholm) 33:281-290

Legg JO, Allison FE (1959) Recovery of ${ }^{15} \mathrm{~N}$-tagged nitrogen from ammonium-fixing soil. Soil Sci Soc Am Proc 23:131-134

Li C, Fan X, Mengel K (1990a) Turnover of interlayer ammonium in loess-derived soil grown with winter wheat in the Shaanxi province of China. Biol Fertil Soils 9:211-214

Li C, Fan X, Mengel K (1990b) Turnover of interlayer ammonium in loess-derived soil grown with winter wheat in loess-derived soil grown with winter wheat in the Shaanxi province of China. Biol Fertil Soils 9:141-155

Liang BC, MacKenzie AF (1994) Fertilization rates and clay fixed ammonium in two Quebec soils. Plant Soil 163:103-109

Liu YL, Zhang B, Li CL, Hu F, Velde B (2008) Long-term fertilization influences on clay mineral composition and ammonium adsorption in rice paddy soils. Soil Sci Soc Am J 72:1580-1590

Lu CY, Zhang XD, Chen X, Shi Y, Ma J, Zhao MQ (2010) Fixation of labelled $\left({ }^{15} \mathrm{NH}_{4}\right)_{2} \mathrm{SO}_{4}$ and its subsequent release in black soil of Northeast China over consecutive crop cultivation. Soil Tillage Res 106:329-334

Lumbanraja J, Evangelou VP (1994) Adsorption-desorption of potassium and ammonium at low cation concentrations in three Kentucky soils. Soil Sci 157:269-278

Lutz JA (1966) Ammonium and potassium fixation and release in selected soils of southeastern United States. Soil Sci 102:366-372

Marschner H (1995) Mineral nutrition of higher plants, 2nd edn. Academic, London

Marzadori C, Vittori Antisari L, Gioacchini P, Sequi P (1994) Turnover of interlayer ammonium in soil cropped with sugar beet. Biol Fertil Soils 18:27-31

Mba-Chibogu B, Meyer B, Narain P (1975) Boden- und Dünger-( ${ }^{15} \mathrm{~N}$-) Stickstoff in Ackerparabraunerden aus Löß: Jahresbilanz und Umverteilung auf verschiedene N-Bindungsformen in Abhängigkeit von Bewuchs, N-Düngungsform und Zusatz von Nitrifikationshemmern. Gött Bodenkdl Ber 34:1-67

McBeth IG (1917) Fixation of ammonium in soils. J Agric Res 9:141-155

Mela Mela P (1962) Fixation of ammonium by clay minerals in relation to probable effects on the vegetative development of plants. Soil Sci 93:189-194

Mengel K, Scherer HW (1981) Release of nonexchangeable (fixed) soil ammonium under field conditions during the growing season. Soil Sci 131:226-232

Mengel K, Horn D, Tributh H (1990) Availability of interlayer ammonium as related to root vicinity and mineral type. Soil Sci 149:131-137

Meyer B, Scheffer K (1970) Veränderungen des N-und K-Haushaltes einer Parabraunerde aus mächtigem Würm-Löß durch Tiefenumbruch. Gött Bodenkdl Ber 16:125-168

Mogilevkina IA (1964) Fixation of ammonium in the soil and method of determining it. Sov Soil Sci 2:185-196

Mohammed ICH (1979) Fixed ammonium in Lybian soils and its availability to barley seedlings. Plant Soil 53:185-196

Moyano A, Gallardo JF (1988) Fixed ammonium determination in some clay soils. Commun Soil Sci Plant Anal 19:225-238

Nannipieri P, Falchini L, Landi L, Benedetti A, Canali S, Tittarelli F, Ferri D, Convertini G, Badalucco L, Grego S, Vitori-Antisari L, Raglione M, Barraclough D (1999) Nitrogen uptake by crops, soil distribution and recovery of urea-N in a sorghum-wheat rotation in different soils under Mediterranean conditions. Plant Soil 208:43-56

Nieder R, Benbi DK (2008) Carbon and nitrogen transformations in soils. In: Nieder R, Benbi DK (eds) Carbon and nitrogen in the terrestrial environment. Springer, Heidelberg, pp 137-159

Nieder R, Neugebauer E, Willenbockel A, Richter J (1995a) Die Rolle der mikrobiellen Biomasse und des mineralisch fixierten Ammoniums bei den Stickstoff-Transformationen in niedersächsischen
Löß-Ackerböden unter Winter-Weizen. I. Poolgrößenveränderungen. Z Pflanzenernahr Bodenkd 158:469-475

Nieder R, Willenbockel A, Neugebauer E, Widmer P, Richter J (1995b) Die Rolle der mikrobiellen Biomasse und des mineralisch fixierten Ammoniums bei den Stickstoff-Transformationen in niedersächsischen Löß-Ackerböden unter Winter-Weizen. II. Umsetzungen von ${ }^{15} \mathrm{~N}$-markiertem Stickstoff. Z Pflanzenernahr Bodenkd 158:477-484

Nieder R, Neugebauer E, Willenbockel A, Kersebaum KC, Richter J (1996) Nitrogen transformation in arable soils of North-West Germany during the cereal growing season. Biol Fertil Soils 22:179-183

Niederbudde EA (1983) Das Tonmineral- $\mathrm{NH}_{4}^{+}$, seine Stellung zu anderen N-Bindungsformen sowie seine Bewertung für $\mathrm{N}$ Immobilisierung und -Mobilisierung in Böden. Kali-Briefe (Büntehof) 16:365-378

Niederbudde EA, Friedrich R (1984) Einfluß von Gülle und Mineraldüngung auf $\mathrm{N}$ - und $\mathrm{K}$-spezifische Bodeneigenschaften einer Geschiebemergel-Braunerde. Bayer Landwirtsch Jahrb 61:781-789

Nommik H (1957) Fixation and defixation of ammonium in soils. Acta Agric Scand 7:395-436

Nommik H (1965) Ammonium fixation and other reactions involving non-enzymatic immobilization of mineral nitrogen in soils. In: Bartholomew WV, Clark FE (eds), Soil nitrogen. Monograph, American Society of Agronomy 10:198-258

Nommik H (1967) Distribution of forms of nitrogen in a podsolic soil profile from Garpenberg, Central Sweden. J Soil Sci 18:301-308

Nommik H (1981) Fixation and biological availability of ammonium in soil clay minerals. Ecol Bull (Stockholm) 33:273-279

Nommik H, Vahtras K (1982) Retention and fixation of ammonium and ammonia in soils. In: Stevenson FJ (ed.) Nitrogen in agricultural soils. Agronomy 22:123-171

Norman RJ, Gilmour JT (1987) Utilization of anhydrous ammonia fixed by clay minerals and soil organic matter. Soil Sci Soc Am J 51:959-962

Opuwaribo E, Odu CTI (1974) Fixed ammonium in Nigerian soils I. Selection of a method and amounts of native fixed ammonium. J Soil Sci 25:256-264

Osborne GJ (1976a) The extraction and definition of nonexchangeable or fixed ammonium in some soils from southern New south Wales. Aust J Soil Res 14:373-380

Osborne GJ (1976b) The significance of intercalary ammonium in representative surface and subsoils from Southern New south Wales. Aust J Soil Res 14:381-388

Paramasivam S, Breitenbeck GA (2000) Quantitative determination of recently fixed non-exchangeable ammonium in soils. Soil Sci Soc Am J 64:1859-1866

Petersburgsky AV, Smirnov PM (1966) Ammonium fixation by some soils in the USSR and the availability of this ion to plants. Plant Soil 25:119-128

Preston CM (1982) The availability of residual fertilizer nitrogen immobilized as clay-fixed ammonium and organic nitrogen. Can J Soil Sci 62:479-486

Prud'homme M (2005) Global nitrogen fertilizer supply and demand outlook. Sci China (Life Sci) 48:818-826

Qi-Xiao W, Li-Li C, Xiao-Hua Z (1995) Fixed ammonium contents and $\mathrm{NH}_{4}^{+}$fixation capacities of some cultivated soils in China. Pedosphere 5:315-323

Rider D, Zasoski RJ, Claassen VP (2005) Ammonium fixation in subgrade decomposed granite substrates. Plant Soil 277:73-84

Rodrigues G (1954) Fixed ammonium in tropical soils. J Soil Sci 5:264-274

Saha D, Mukhopadhyay AK (1986) Availability of residual fixed ammonium to crops. Biol Fertil Soils 2:83-86 
Sahrawat KL (1995) Fixed ammonium and carbon-nitrogen ratios of some semi-arid tropical Indian soils. Geoderma 68:219-224

Said MB (1973) Ammonium fixation in the Sudan Gezira soils. Plant Soil 38:9-16

Schachtschabel P (1960) Fixierter Ammoniumstickstoff in Löss- und Marschböden. Trans 7th Int Congr Soil Sci 2:22-27

Schachtschabel P (1961) Bestimmung des fixierten Ammoniums im Boden. Z Pflanzenernaehr Düng Bodenkd 93:125-136

Scheffer F, Meyer B (1970) Zielsetzungen und Analyse eines Tiefumbruch-Versuches auf einer grundwasserfernen Löß- Parabraunerde in Süd- Niedersachsen. Gött Bodenkdl Ber 16:1-169

Scherer HW (1982) Fixed $\mathrm{NH}_{4}-\mathrm{N}$ in relation to EUF-extractable K. Plant Soil 64:67-71

Scherer HW (1984) Beziehung zwischen dem Stickstoff-Entzug der Pflanzen und der Abnahme von spezifisch gebundenem $\mathrm{NH}_{4}-\mathrm{N}$ im Boden. Z Pflanzenernahr Bodenkd 147:29-36

Scherer HW (1985) Wechselwirkungen zwischen $\mathrm{NH}_{4}{ }^{+}$und $\mathrm{K}^{+}$bei der spezifischen Bindung und der Mobilisierung im Boden. KaliBriefe (Büntehof) 17:431-440

Scherer HW (1986) Dynamik und Pflanzenverfügbarkeit von Zwischenschicht-Ammonium der Tonminerale in Landwirtschaftlich genutzten Böden. Habilitation thesis, University of Gießen, Germany

Scherer HW (1987) Zur Verfügbarkeit von ZwischenschichtAmmonium der Tonminerale. Landwirtsch Forsch 40:259-276

Scherer HW (1993) Dynamics and availability of the nonexchangeable $\mathrm{NH}_{4}{ }^{+}-\mathrm{N}$-a review. Eur J Agron 2:149-160

Scherer HW, Ahrens G (1994) Untersuchungen zum Stickstoffumsatz in der Rhizosphäre. Ökophysiol Wurzelraumes 5:127-131

Scherer HW, Ahrens G (1996) Depletion of non-exchangeable $\mathrm{NH}_{4}{ }^{+}-$ $\mathrm{N}$ in the soil-root interface in relation to clay mineral composition and plant species. Eur J Agron 5:1-7

Scherer HW, Mengel K (1979) der Gehalt an fixiertem Ammoniumstickstoff auf einigen repräsentativen hessischen Standorten. Landwirtsch Forsch 32:416-424

Scherer HW, Mengel K (1986) Importance of soil type on the release of nonexchangeable $\mathrm{NH}_{4}{ }^{+}$and availability of fertilizer $\mathrm{NH}_{4}{ }^{+}$and fertilizer $\mathrm{NO}_{3}{ }^{-}$. Fertil Res 8:249-258

Scherer HW, Zhang YS (1999) Studies on the mechanism of fixation and release of ammonium in paddy soils after flooding. I. Effect of iron oxides on ammonium fixation. J Plant Nutr Soil Sci 162:593-597

Scherer HW, Zhang YS (2002) Mechanisms of fixation and release of ammonium in paddy soils after flooding. III. Effect of the oxidation state of octahedral $\mathrm{Fe}$ on ammonium fixation. J Plant Nutr Soil Sci 165:185-189

Schiller H, Wallicord A (1964) Das Verhältnis Kaliumfixierung/ Ammoniumfixierung im Boden - ein ertragsbestimmender Faktor. Z Pflanzenernahr Dung Bodenkd 104:119-130

Schneiders M, Scherer HW (1996) The influence of "puddling" on redox potential, fixation and release of nonexchangeable ammonium and ist effect on rice growth in flooded soils. In: Van Ittersum MK, Venner GEGT, van den Geijn SC, Jetten TH (eds) Proceedings of the 4th ESA Congress, Veldhoven-Wageningen, The Netherlands 7-11 July, 1996, European Society of Agronomy, p 374-375

Silva JA, Bremner JM (1966) Determination and isotope-ratio analysis of different forms of nitrogen in soils: 5. Fixed ammonium. Soil Sci Soc Am Proc 30:587-593

Skonde EI, Koroleva IYE, Shcherbakov AP (1974) Reserves and forms of nitrogen in the Chernozems of the east European facies. Sov Soil Sci 6:553-558
Smith SJ, Power JF, Kemper WD (1994) Fixed ammonium and nitrogen availability indexes. Soil Sci 158:132-140

Sommer K, Scherer HW (2009) Source/sink relationships in plants as depending on ammonium as "cultan", nitrate or urea as available nitrogen fertilizers. Acta Hortic (ISHS) 835:65-87

Soon YK (1998) Nitrogen cycling involving non-exchangeable ammonium in a gray luvisol. Biol Fertil Soils 27:425-429

Sowden FJ (1976) Transformations of nitrogen added as ammonium and manure to soil with a high ammonium-fixing capacity under laboratory conditions. Can J Soil Sci 56:319-331

Sowden FJ, Maclean AA, Ross GJ (1978) Native clay fixed ammonium content and the fixation of added ammonium of some soils of Eastern Canada. Can J Soil Sci 58:27-38

Sparks DL, Blevins RL, Bailey HH, Barnhisel RI (1979) Relationship of ammonium nitrogen distribution to mineralogy in a Hapludalf soil. Soil Sci Soc Am J 43:786-789

SSSA (1984) Glossary of soil science terms. Soil Sci Soc Am, Madison, Wisconsin

Stanford G, Pierre WH (1947) The relation of potassium fixation to ammonium fixation. Soil Sci Soc Am Proc 11:155-160

Steffens D, Sparks DL (1997) Kinetics of nonexchangeable ammonium release from soils. Soil Sci Soc Am J 61:455-462

Steffens D, Sparks DL (1999) Effect of residence time on the kinetics of nonexchangeable ammonium release from illite and vermiculite. J Plant Nutr Soil Sci 162:599-604

Stucki JW, Golden DC, Roth CB (1984) Effects of reduction and reoxidation of structural iron and clay swelling. Clays Clay Miner 32:350-356

Tang Y, Wang XZ, Zhao HT, Feng K (2008) Effect of potassium and C/N ratios on conversion of $\mathrm{NH}_{4}^{+}$in soils. Pedosphere 18:539-544

Van Praag HJ, Fischer V, Riga A (1980) Fate of fertilizer nitrogen applied to winter wheat as $\mathrm{Na}^{15} \mathrm{NO}_{3}$ and $\left({ }^{15} \mathrm{NH}_{4}\right)_{2} \mathrm{SO}_{4}$ studied in microplots through a four-course rotation: 2. Fixed ammonium turn-over and nitrogen reversion. Soil Sci 130:100-105

Welch LF, Scott AD (1960) Nitrification of fixed ammonium in clay minerals as affected by added potassium. Soil Sci 90:79-85

Williams WA, Mikkelsen DS, Mueller KE, Ruckman JR (1968) Nitrogen immobilization by rice straw incorporated in lowland rice production. Plant Soil 28:49-60

Wlotzka F (1961) Untersuchungen zur Geochemie des Stickstoffs. $\mathrm{PhD}$ thesis, Universität Göttingen

Yaalon DH, Feigin A (1970) Non-exchangeable ammonium ions in some clays and shales of Israel. Isr $\mathrm{J}$ Chem 8:425434

Zhang YS, Scherer H (1998) Simplification of the standard method for determination of non-exchangeable $\mathrm{NH}_{4}^{+}-\mathrm{N}$ in soil. Z Pflanzenernahr Bodenkd 161:101-103

Zhang YS, Scherer H (1999) Ammonium fixation by clay minerals in different layers of two paddy soils after flooding. Biol Fertil Soils 29:152-156

Zhang YS, Scherer H (2000) Mechanism of fixation and release of ammonium in paddy soils after flooding. II. Effect of transformation of nitrogen forms on ammonium fixation. Biol Fertil Soils 31:517-521

Zhang YZ, Liao JE, Sun YH, Feng YH, Huang YX (2003) Fixed ammonium in major paddy soils in Hunan province, China. Pedosphere 13:199-208

Zhang YZ, Huang SH, Wan DJ, Huang YX, Zhou WJ, Zou YB (2007) Fixed ammonium content and maximum capacity of ammonium fixation in major types of tilled soils in Hunan Province, China. Agric Sci China 6:466-474 